\title{
ALGAE COMMENSAL COMMUNITY IN GENLISEA TRAPS
}

\author{
BARTOSZ JAN PŁACHNO ${ }^{1}$, KONRAD WOŁOWSKI ${ }^{2}$ \\ ${ }^{1}$ Department of Plant Cytology and Embryology, \\ The Jagiellonian University \\ Grodzka 52, 31-044 Kraków, Poland \\ ${ }^{2}$ Department of Phycology, \\ Institute of Botany Polish Academy of Sciences \\ Lubicz 46, 31-512 Kraków, Poland \\ e-mail: ibwolowski@ib-pan.krakow.pl \\ (Received: April 5, 2006. Accepted: July 16, 2007)
}

\begin{abstract}
The community of algae occurring in Genlisea traps and on the external traps surface in laboratory conditions were studied. A total of 29 taxa were found inside the traps, with abundant diatoms, green algae (Chlamydophyceae) and four morphotypes of chrysophytes stomatocysts. One morphotype is described as new for science. There are two ways of algae getting into Genlisea traps. The majority of those recorded inside the traps, are mobile; swimming freely by flagella or moving exuding mucilage like diatoms being ablate to colonize the traps themselves. Another possibility is transport of algae by invertebrates such as mites and crustaceans. In any case algae in the Genlisea traps come from the surrounding environment. Two dominant groups of algae (Chladymonas div. and diatoms) in the trap environment, show ability to hydrolyze phosphomonoseters. We suggest that algae in carnivorous plant traps can compete with plant (host) for organic phosphate (phosphomonoseters). From the spectrum and ecological requirements of algal species found in the traps, environment inside the traps seems to be acidic. However, further studies are needed to test the relations between algae and carnivorous plants both in laboratory conditions and in the natural environment. All the reported taxa are described briefly and documented with 74 LM and SEM micrographs.
\end{abstract}

KEY WORDS: algae, carnivorous plants, Genlisea, commensalisms, phosphatase, phosphomonoseters, enzyme activity, ELF97 phosphate, phytotelmata, Lentibulariaceae, carnivorous syndrome, plantmicrobe interaction.

\section{INTRODUCTION}

Carnivorous plants attract trap animals and finally utilize nutrients from their carcasses to supplement nutrition, but some of them are also phytotelmata (Juniper et al. 1989). The most complicated mutualistic interactions have evolved in those carnivorous plants which form large pitchertype traps, mainly Nepenthes and Sarracenia (e.g., Juniper et al. 1989; Miller et al. 2002; Ellison et al. 2003; Gray et al. 2006). Moreover some provide an excellent environment for rich algae flora (Gebühr et al. 2006). The bladders of Utricularia forming tiny traps also support communities of several algae and microinvertebrates (e.g., Schumacher 1960; Botta 1976; Mosto 1979; Richards 2001; Adamec and Komárek 1999a, b). According to Juniper et al. (1989) Genlisea traps lack commensals. In contrast to Utricularia, there is only scarce information about algae in Genlisea traps (Goebel 1891, Tab. XV Fig. 5; Studnička 1996; Płachno et al. 2005a, b), none of which is detailed. The carnivorous rootless genus Genlisea (Lentibulariaceae), with about 21 species, is restricted to South and Central America, Africa and Madagascar, and occurs in nutrientpoor habitats such as: ferricretes, inselbergs, savannas, swamps and wet meadows (Taylor 1991; Fischer et al. 2000). Similarly to other carnivorous plants, Genlisea ("corkscrew plant") has an additional source of nutrients by trapping and utilizing prey, small invertebrates e.g. rotifers, nematodes, crustaceans (Płachno et al. 2005) and protozoa (Barthlott et al. 1998). In order to achieve this, Genlisea forms eel/lobster-pot traps, which are submerged in wet soil. The single trap, which is a hollow utricle, consists of stalk, bulb, tubular channel (neck), and two helically twisted arms with openings (e.g., Lloyd 1942; Heslop-Harrison 1975; Reut 1993).

The main aim of this study was to determine algal species in Genlisea traps in laboratory conditions. Additionally, we detect enzyme production of algal commensals within trap environment using the ELF assay previously used for detection of phosphatase (phosphomonoesterase) activity in carnivorous plants (see Płachno et al. 2006) and 
plankton (e.g. Nedoma et al. 2003; Štrojsová et al. 2003; Štrojsová and Vrba 2005; Cao et al. 2005).

\section{MATERIAL AND METHODS}

Plant material: Genlisea hispidula Stapf, G. lobata Fromm-Trinta, G. violacea St.-Hil. f. Giant, G. pygmaea St.-Hil., G. repens Benjamin and hybrid Genlisea lobata $\mathrm{x}$ Genlisea violacea $\mathrm{f}$. Giant were cultivated in the Department of Plant Cytology and Embryology, Jagiellonian University. They were grown in pots in a mixture of wet peat and sand. The peat, which was brought from marshes, contained a natural community of small organisms.

In order to observe algae in situ inside the traps, samples were prepared for SEM according to procedures elsewhere (Płachno et al. 2005a, b). Samples for detailed taxonomic analysis were prepared and cleaned by standard techniques (Krammer and Lange-Bertalot 1986). Material was viewed with Hitachi S-4700 SEM (Scanning Microscopy Laboratory of Biological and Geological Sciences, Jagiellonian University).

For detection extracellular enzyme production of algal commensals we used ELF $^{\circledR} 97$ phosphatase substrate (ELFP, Molecular Probes). The substrate is cleaved in the presence of phosphatases into ELF $^{\circledR} 97$ alcohol, which has intensive, bright yellow-green fluorescence (Huang et al. 1992; Larison et al. 1995; see also Whitton at al. 2005). Briefly, the traps and soil samples were incubated in the substrate solution (c. $250 \mu \mathrm{M}$ of ELFP in distilled water) at room temperature. For some samples DAPI was added to label DNA and make nucleus more visible. The traps were then screened for ELF (yellow-green), chlorophyll a (red) and DAPI (blue) fluorescence in an epifluorescence microscope (Nikon Eclipse E 400 with the UV-2A filter). Documentation was made on Sensia 100 slide films. Observations of chlorophyll fluorescence were also helpful in determining the shape and size of chloroplasts.

\section{RESULTS}

Algae occur both inside the traps and also on the external trap surface. They were found in all the trap parts: arm, neck and bulb. In the neck, the algae frequently accumulated along the rows of secretory hairs. The external trap surface provides a solid substratum for epiphytic algae, especially the arms of the giant traps in G. pygmaea and G. repens, which grow on the surface of peat and have access to light. In this case algae were commonly observed in close proximity to the external secretory hairs.

\section{Cyanophyta (=Cyanobacteria)}

Synechocystis aquatilis Sauvageau

Figs 1 and 2

Cells globular to widely ovoid, solitary or two together (3.7)-6.0-7.1(8.0) $\mu \mathrm{m}$ in diameter. Only few specimens were observed. This organism, which occurs in stagnant or slow-flowing water bodies, is probably common, but rarely reported from Europe (Starmach 1966; Komarek and Anagnostidis 1998). Widespread, common.
Planktothrix conf. agardhii Gomont

Fig. 3

Filaments light-blue-green, cells ca. $2.5 \mu \mathrm{m}$ long, ca. 4.7 $\mu \mathrm{m}$ wide, with small granulation at the cross wall. Only few filament were observed in the trap. Cosmopolitan, widespread.

\section{Heterokontophyta \\ Chrysophyceae}

Chromulina conf. bicocca Schiller $\quad$ Figs 9 and 10

Cells broadly ovoid, irregular, periplast covered with small papilla, 10-12.0 $\mu \mathrm{m}$ in diameter, chloroplast yellowgreen. Palmelloid aggregates were observed. Several specimens were observed in the traps. Not common, reported from Neusiedlersee Austria. Note: Our specimens were smaller than those described by Schiller (after Starmach 1985: 12-22 um long, 12-18 wide).

Mallomonas conf. globosa Schiller

Figs 27 and 28

Cells circular, ca. $10 \mu \mathrm{m}$ in diameter, covered by smooth scales with long bristles. Only few specimens were observed in and outside on the external of the trap surface. Not common, reported from plankton of old river bed in Austria. Note: Our specimens were a little smaller than those described by Schiller (after Starmach 1985: 12-13 $\mu \mathrm{m}$ in diameters. It can only be stomatocyst of Mallomonas globosa still attached by scales.

\section{Stomatocyst 183 Brown \& Smol in Brown et al. (1994)}

Fig. 29

Cyst spherical, smooth, $5.23 \mu \mathrm{m}$ in diameter; collar cylindrical 1.5 in diameter, 0.5-0.7 high, surrounding a regular pore, 0.3 in diameter. Single specimen was observed inside the trap. Common.

Stomatocyst unidentified Wołowski \& Płachno Fig. 30 Cyst spherical, $5.7 \mu \mathrm{m}$ in diameter, ornamented, ornamentations consist of regularly scattered echinate spine pattern. Only single specimen was observed. Note: Because the details of the collar and apical pore were not visible we cannot identify observed stomatocyst.

Stomatocyst 1 Cabała 2002

Figs 31 and 32

Cyst spherical 13-15 $\mu \mathrm{m}$ in diameter, covered with 5-7-9 spines, slightly wider at the base, straight; collar with flat planar annulus 2.3-3 $\mu \mathrm{m}$ in diameter, ca. 0.5-1 $\mu \mathrm{m}$ high, apical pore 1.2-1.3 $\mu \mathrm{m}$ in diameter. Many specimens were observed. Probably common. Note: Dimension of the stomatocyst is a little bigger than Stomatocyst 1 Cabała 2002. but the rest of the features are the same.

\section{Stomatocyst 1 Wołowski \& Płachno (this paper)}

Figs 33-38

Negative number: P5-21 Figs: 33-38, from traps of Genlisea plants cultivated in Department of Plant Cytology and Embryology Jagiellonian University,

Number of specimens: 5

SEM descriptions: Stomatocyst spherical 14-15.3 $\mu \mathrm{m}$ in diameter, covered with 6-7 spines $\mu$ m long, slightly wider at the base, bifurcate at the ends, distributed over the surface; regular pore $0.7-1 \mu \mathrm{m}$ in diameter with flat planar annulus, (Fig. 33), obconical collar, $1.7 \mu \mathrm{m}$ high, sometimes with well visible siliceous plug (Fig. 34), collar margin is irregularly folded and turned-down, 4.5-5.7 in diameter at 

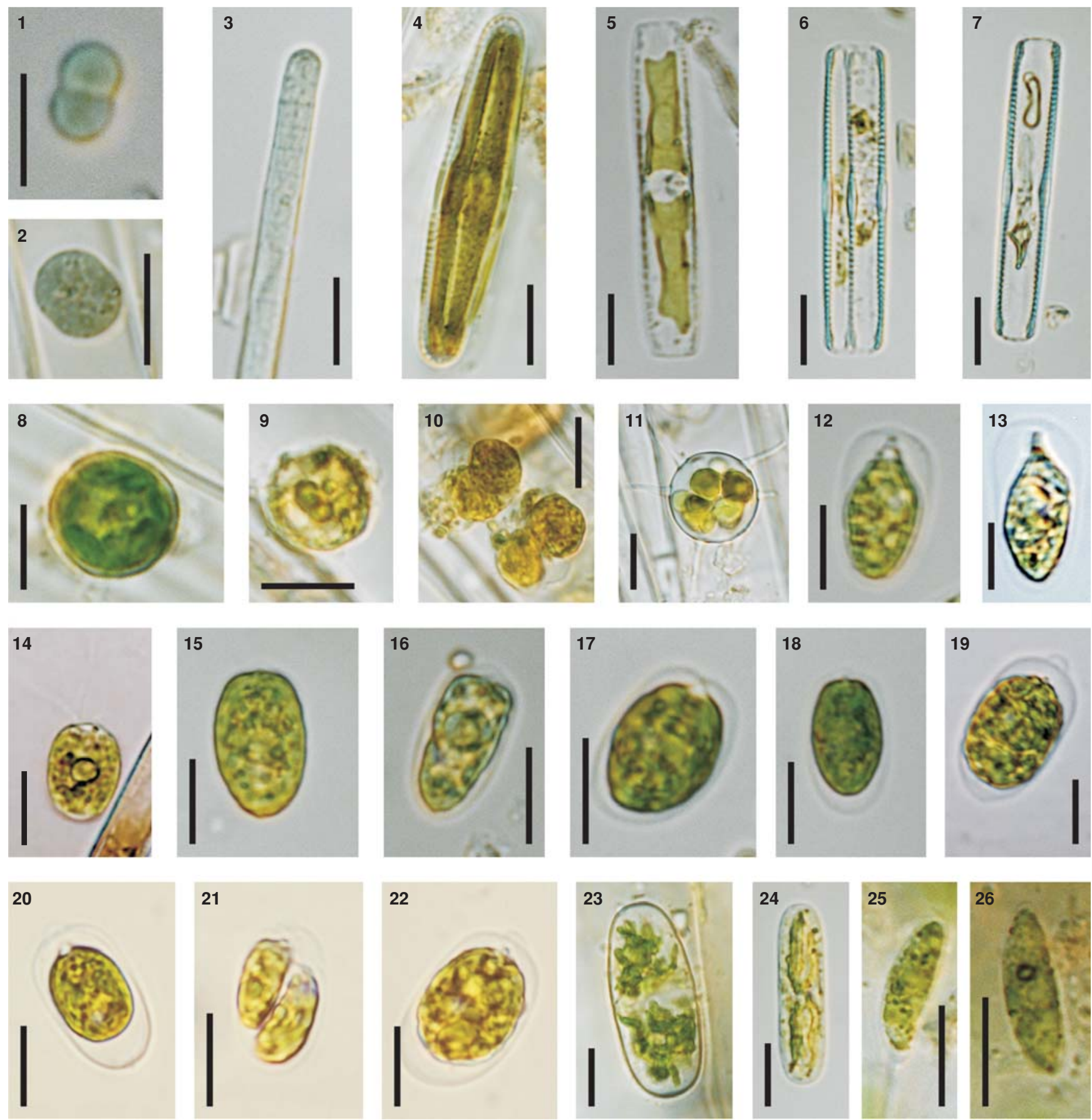

Figs 1-2. Synechocistis aquatilis, cell in various focus. Fig. 3. Planktothrix conf. agardhii, apical part of trychome. Figs 4-7. Pinnularia permicrostauron; Fig. 4 - cell in front view; Fig. 5 - cell in lateral; Figs 6-7 - valves in lateral views. Fig. 8. Chlorococcal form of cell. Figs 9-10. Chromulina bicocca; Fig. 9 - single cell; Fig. 10 - cells during division. Fig. 11. Stomatocyst 183 Brown \& Smol with well visible chloroplasts and drops of chrysolaminaryna. Figs 12-13. Sphaerelopsis alpine. Figs 14-15. Chlamydomonas sp. 1. Figs 16-18. Chlamydomonas sp. 2. Figs 19-22. Chlamydomonas sp. 3 ; Fig. 21 - cells after division. Figs 23-24. Actinotaenium cruciferum; Fig. 23 - cell in front view; Fig 24 - cell in lateral view. Figs 25-26. Chlorogonum conf. fusiforme - cells without flagella. Scale bar $=10 \mu \mathrm{m}$.

the apex (Figs 35-36). Note: similar to stomatocyst 80 Hansen 2001, but our specimens were bigger and had larger margin surrounding apical and regular pore, and to the stomatocyst 42 Piątek 2007, but our cyst had regular pore with planar pseudoannulus. Morphologically comparable with stomatocyst reported previously by Buczkó and Wojtal (2005, p. 37, Fig. 69) from Hungarian peat bogs, but wrongly described as stomatocyst S062 Pla 2001, which has different collar and ornamentation.

\section{Bacillariophyceae}

Navicula minima Grunow

Fig. 39

Valves small, elliptical with rounded apices, 10 um long, $3.23 \mu \mathrm{m}$ wide, striae density 10-14/10 um. Single specimen was observed inside the traps. Cosmopolitan, widespread.

\section{Navicula festiva Kraske}

Fig. 40.

(= Frustulia vitrea Östrup, Navicula vitrea (Östrup) Hustedt) 

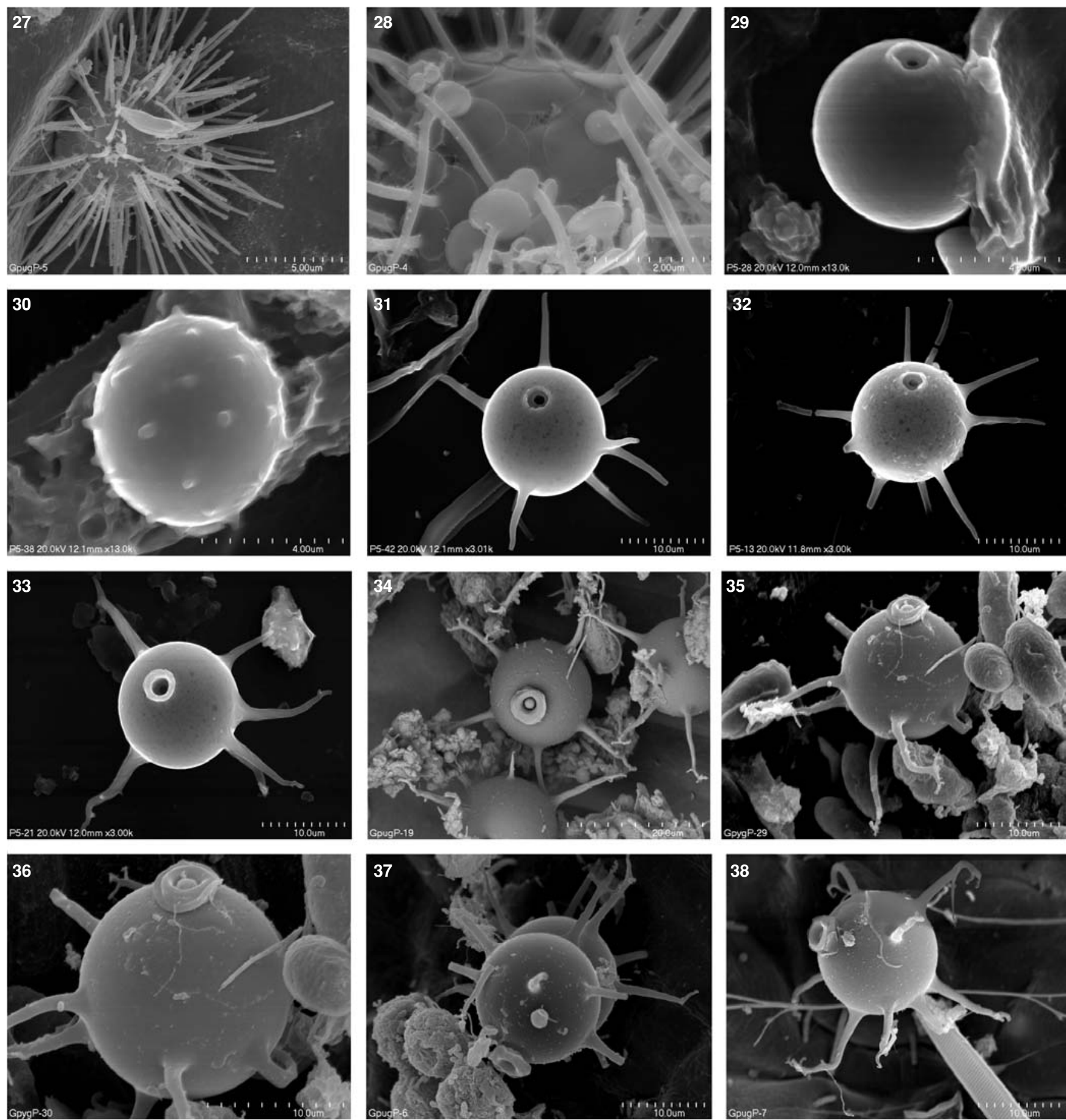

Figs 27-28. Mallomonas conf. globosa; Fig. 27 - general view of cell; Fig. 28 - detail view of bristles and scales. Fig. 29. Stomatocyst 183 Brown \& Smol. Fig. 30. Stomatocyst unidentified Wołowski \& Płachno. Figs 31-32. Stomatocyst 1 Cabała 2002. Figs 33-38. Stomatocyst 1 Wołowski \& Płachno; Fig. 33 - cyst without plug; Figs 34-38 - stomatocysts in various view (SEM).

Valve elliptical to linear lanceolate with rounded apices, ca. $13.8 \mu \mathrm{m}$ long, $4.6 \mu \mathrm{m}$ wide, striae density 24/10. Several specimens were observed inside the traps. Cosmopoli$\tan$.

Frustulia crassinervia (Bréb) Lange-Bertalot \& Krammer Figs 41 and 42

Valve broadly lanceolate with slightly rostrate, 45 $\mu \mathrm{m}$ long, $11.2 \mu \mathrm{m}$ wide, striae density: $34 / 10 \mu \mathrm{m}$, more or less parallel; axial area straight with a pair of thick and parallel ribs around the raphe. Several specimens were observed. Cosmopolitan.
Eunotia bilunaris (Her.) Mills

Fig. 43

Valve slightly dorsi-ventral, with rounded and unmodified apices, ca. 20 um long, ca. 4 um wide, striae density $17 / 10 \mu \mathrm{m}$ parallel. Few specimens were observed inside the traps. Common.

Eunotia exigua (Brébisson ex Kützing) Rabenhorst

Fig. 44

Valves dorsi-ventral, 10.5-13.5 um long, 3.7-4.1 um wide, slightly narrowing towards the ends; striae parallel and slightly denser near the apices, striae density ca. 26/10 um. Several specimens were observed in the traps. Acidobiotic, common. 

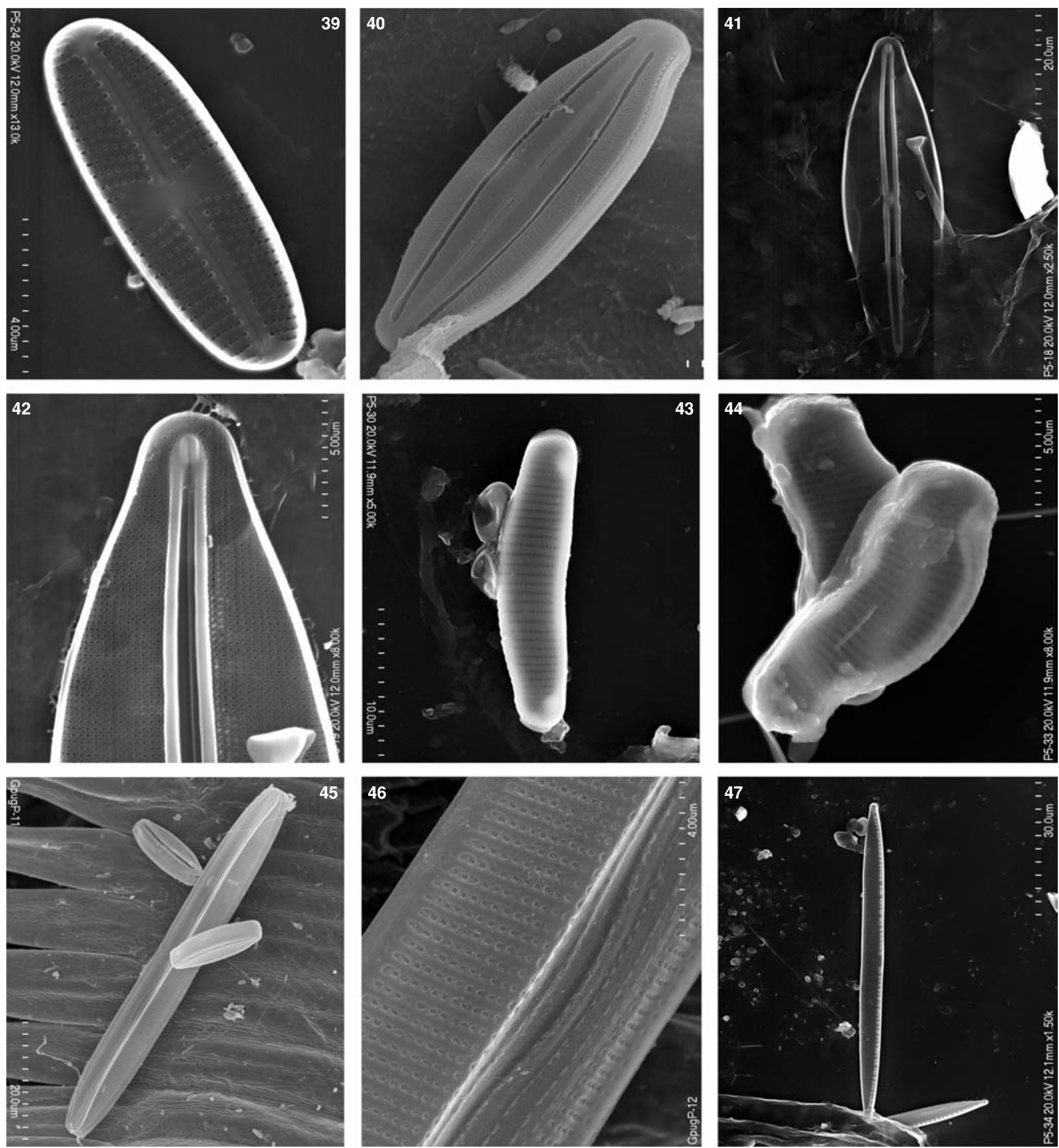

Fig. 39. Navicula minima, internal view of valva. Fig. 40. Navicula festiva, general view. Figs 41-42. Frustulia crasinervia; Fig. 41 - general view of frustules; Fig. 42 - apical part with well visible structure of valve. Fig. 43. Eunotia bilunaris. Fig. 44. Eunotia exigua, damage valves. Figs 45-47. Nitzschia linearis; Fig. 45 - valves of N. linearis and two frustules of Navicula festiva lying on trap surface; Fig. 46 - detail of valve structure in central part; Fig. 47 - general view of valve (SEM).

Nitzschia linearis W. Smith

\section{(= Frustulia linearis $\mathrm{C}$. Agardh)}

Valve linear, slightly narrowed and rounded at the apices, 50-72.6 $\mu \mathrm{m}$ long, 4.0-7.5 $\mu \mathrm{m}$ wide, raphe keel narrow, fibulae density: $13 / 10$, striae density $24-27 / 10$. Several specimens were observed inside the traps. Common, widespread.

\section{Nitzschia capitellata Hustedt}

Fig. 49

Valve linear-lanceolate with attenuated ends and round to weakly capitate apices, $25.7 \mu \mathrm{m}$ long, $3.5 \mu \mathrm{m}$ wide, keel narrow, linear fibulae density: 13/10 um, striae density ca. $30-40 / 10 \mu \mathrm{m}$. Several specimens were observed inside the traps. Widespread but not common.

Pinnularia subcapitata Gregory var. elongata Krammer Figs 50, 51, 70, 71

Valve linear, slightly narrowing at the ends, distinctly capitate, ca. $44 \mu \mathrm{m}$ long, ca. $7.8 \mu \mathrm{m}$ wide, striae density: 11$-13 / 10 \mu \mathrm{m}$, parallel to radiate in the middle, parallel to convergent at the ends. Many specimens were observed inside the traps. Probably common. 

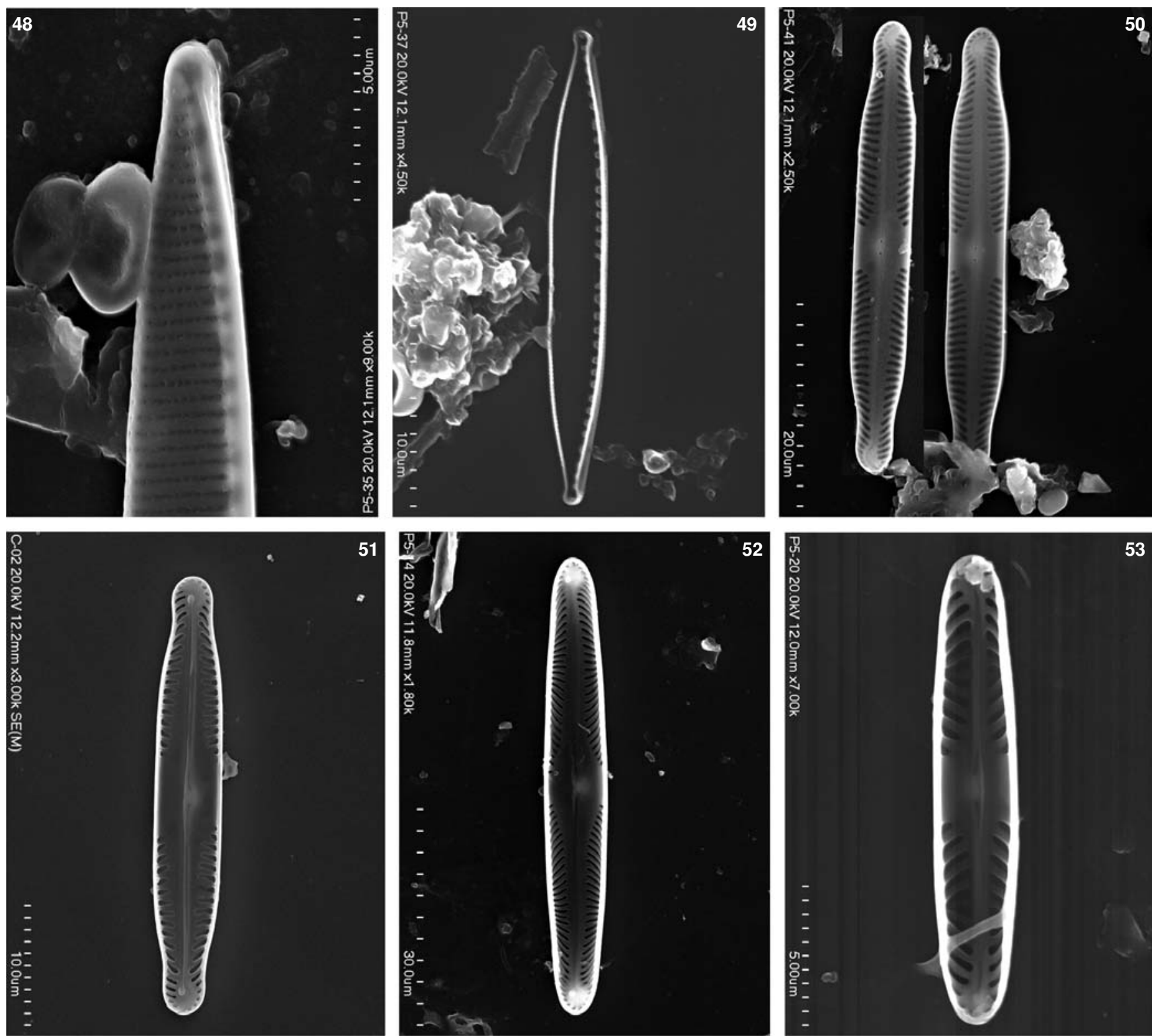

Fig. 48. Nitzschia linearis, detail of valve structure at the apical part. Fig. 49. Nitzschia capittelata with well visible short fibulae of keel. Figs 50-51. Pinnularia subcapitata; Fig. 50 - exterenal view of two valves; Fig. 51 - detail structure from the internal view of valve. Fig. 52. Pinnularia conf. permicrostauron, internal view of valve. Fig. 53. Pinnularia acidophila, internal view of valve (SEM).

\section{Pinnularia conf. permicrostauron}

Cramer \& Metzeltin

Figs $52,72,73$

Valve linear with almost parallel sides, ends long broadly truncate protracted, 44.5-63.0 $\mu \mathrm{m}$ long, 8.8-9.4 $\mu \mathrm{m}$ wide, striae density: $11 / 10 \mu \mathrm{m}$, radiate in the middle, convergent at the ends. Only ventral valve was observed (Fig. 52).

Pinnularia acidophila Hofmann \& Krammer Fig. 53

Valve linear-lanceolate ca. $16.8 \mu \mathrm{m}$ long, ca. $3.0 \mu \mathrm{m}$ wide, with straight to weakly convex sides, rounded at the apices, raphe branches filiform, striae density: 14-16/10, radiate in the middle part of valve becoming strongly convergent at the ends. Few specimens were observed inside the traps. Acidobiontic, common.

\section{Euglenophyta}

Euglenophyceae

\section{Euglena mutabilis Schmitz}

Cells narrowly-cylindrical, slightly narrowed at the anterior end, strongly flexible in shape, 60-65 $\mu \mathrm{m}$ long, 5-7 $\mu \mathrm{m}$ wide. Many specimens were observed inside one trap. Acidobiontic, common (Wołowski \& Hindak 2005).

\section{Trachelomonas hispida (Perty) Stein var. hispida}

Figs 62 and 63

Lorica elliptic, punctuate and covered with short spines, 22.7 long, $15 \mu \mathrm{m}$ wide. Two specimens were observed inside the traps. Cosmopolitan, widespread (Wołowski 1998).

\section{Chlorophyta}

Sphaerellopsis alpina Pascher

Figs 12 and 13

Cells elliptic-cylindrical, 14.5-23 um long, 9.5-10 $\mu \mathrm{m}$ wide with two flagella (which are not presented on our micrographs), cell wall gentle, in the apical part of cell extended from protoplast, at the posterior end only slightly or not extended. Several specimens were observed inside the traps. Not common, reported from Austria (Ettl 1983). 

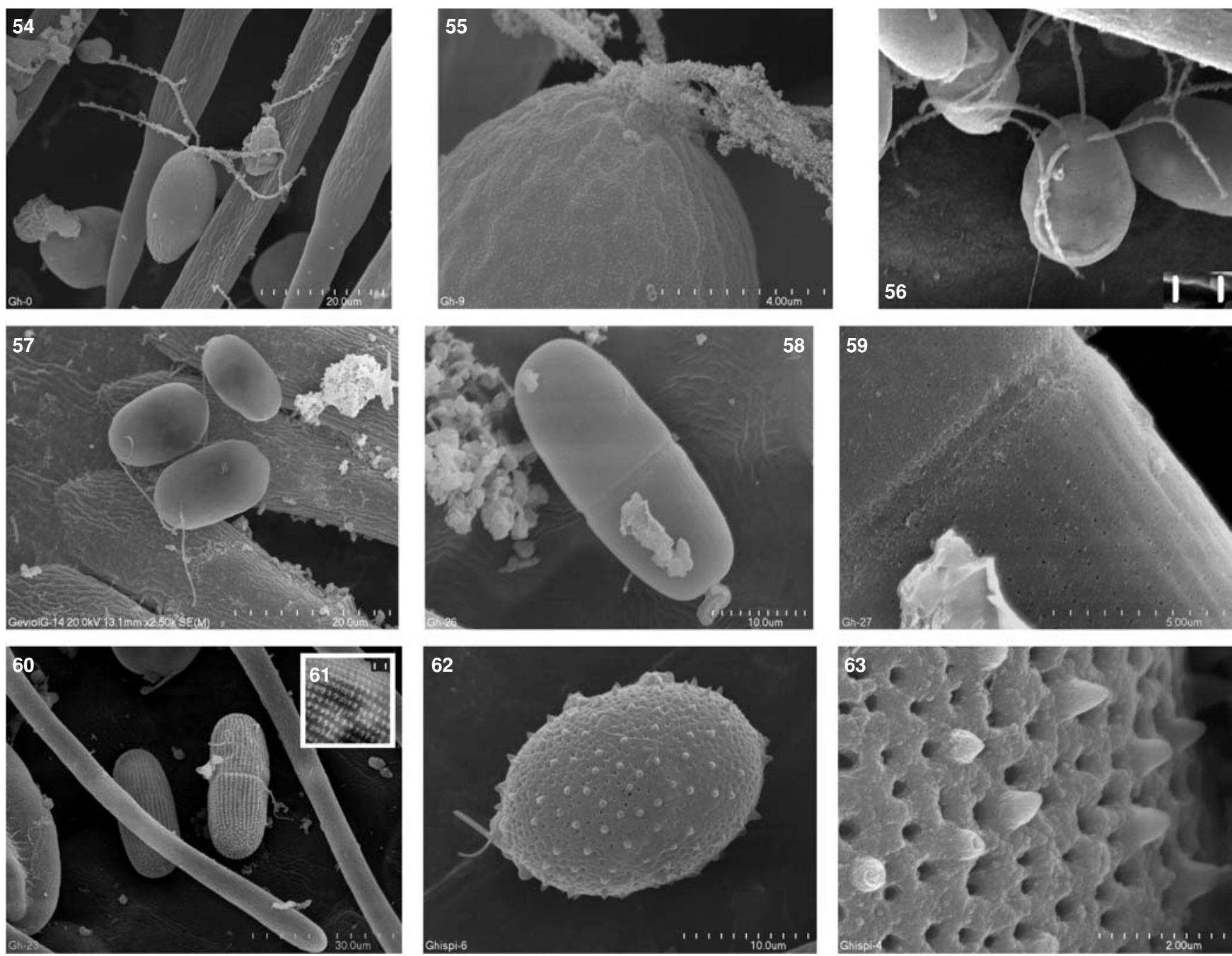

Figs 54-55. Carteria conf. quadrilobulata; Fig. 54 - cells with for flagella lying on the hairs inside Genlisea hispidula trap; Fig. 55 - papilla with flagella in high magnification. Figs 56-57. Carteria conf. geminata. Fig. 56 - cell with four flagella; Fig. 57 - cells with damaged flagella lying on the hairs inside Genlisea violacea trap. Figs 58-59. Actinotaenium cruciferum; Fig. 58 - general view of cell; Fig. 59 - detail view of wall structure around the shallow sinus. Figs 60-61. Penium cylindrus; Fig. 60 - general view of cell with well visible shallow sinus; Fig. 61 - detail wall structure; Trachelomonas hispida. Fig. 62. general view of lorica. Fig. 63. Detail view of lorica wall structure (SEM).

\section{Chlamydomonas sp. 1.}

Figs 14, 15, 64-65

Cell broadly ellipsoidal 12-16-20 um long, 9-10-13 $\mu \mathrm{m}$ wide, with small prominent papilla, chloroplast with centrally placed pyrenoid. Note: Because the details of cell organelle were not visible we cannot determinate the observed specimens. Occurred in mass inside the traps.

\section{Chlamydomonas sp. 2}

Figs 16-18, 66-67

Cells ovoid to broadly elliptical 12.5-14-16-18.5-21.8 $\mu \mathrm{m}$ long, 6.5-13.5 $\mu \mathrm{m}$ wide, with small conical papilla, protoplast more or less detached from cell wall. Note: Because the details of cell organelle were not visible we cannot determinate the observed specimens. Occurred in mass inside the traps.

\section{Chlamydomonas sp. 3}

Figs 19-22

Cells broadly elliptical 13.5-19.0 um long (together with protoplast) 9.1-13.3 $\mu \mathrm{m}$ wide, with small conical papilla, protoplast evidently detached from cell wall at the anterior and posterior parts Note: Because the details of cell organelle were not visible we cannot determinate the observed specimens. Occurred in mass inside the traps.
Carteria conf. quadrilobulata Skuja

Figs 54 and 55

Cells ellipsoidal, ca. $20.0 \mu \mathrm{m}$ long, $10.9 \mu \mathrm{m}$ wide, papilla flat at the top, with four flagella rising from the side wall of papilla, located opposite, occurred abundantly, was observed inside the traps. Note: We did not see the details of cells in LM but in SEM.

Carteria conf. geminata Ettl Figs 56 and 57, 68-71

Cells ovoid to egg shaped, ca. 17.6-18 $\mu \mathrm{m}$ long, 12.5-13 $\mu \mathrm{m}$ wide, without papilla, four opposite flagella, placed lower the top of cell. Occurred abundantly inside the traps together with Carteria cof. quadrilobulata. Note: We did not observe the details of cells in LM but only in SEM specimens were observed. Our specimens were a little bigger than those described by Ettl (1964): 10-16 long, 6-12 wide; taxa also similar to C. ellipsoidalis Bold which is decidedly broadly-ellipsoidal in shape.

\section{Chlorogonium conf. fusiforme Matwienko}

Figs 25 and 26

Cells spindle form 12.5-15.5 um long, 4-4.2 $\mu \mathrm{m}$ wide, chloroplast parietal, cell with single approximately median pyrenoid. Note: Because we observed only specimens 

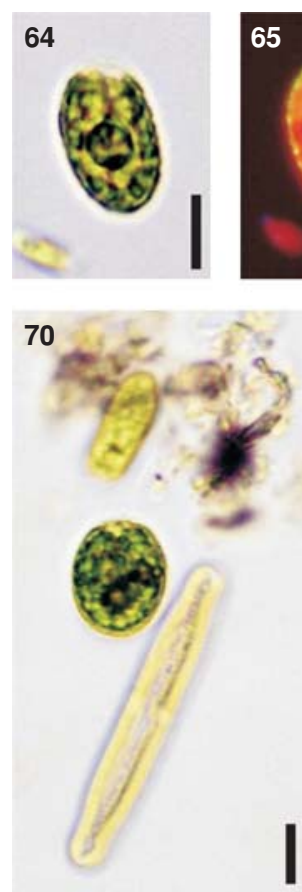
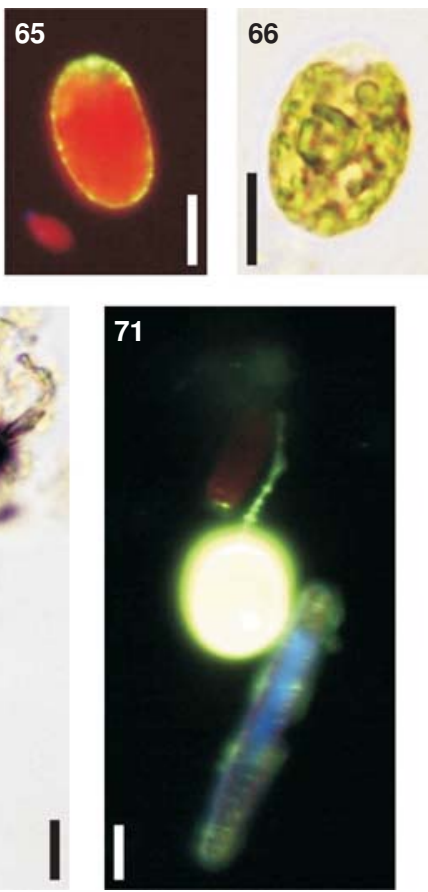

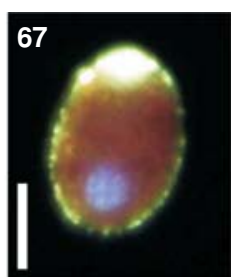

72

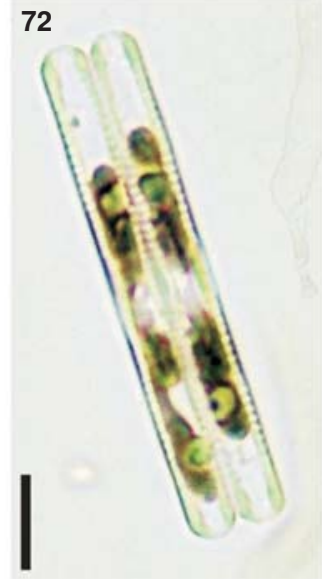

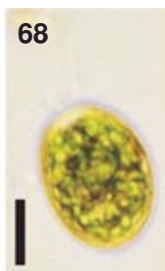
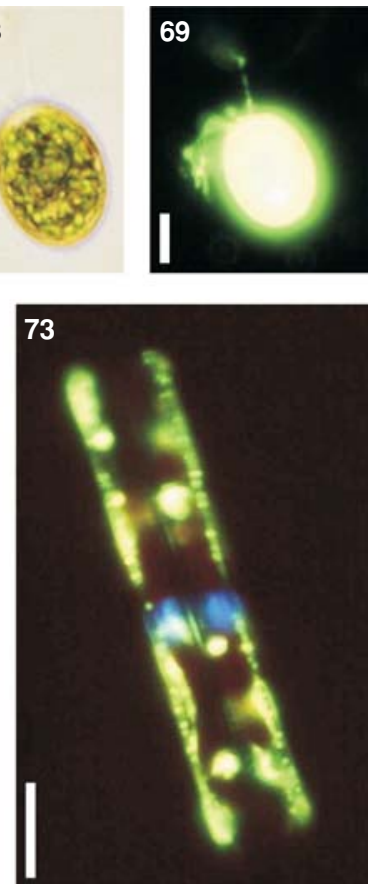

Figs 64-65. Chlamydomonas sp. 1; Fig. 64 - cell with well visible pyrenoid; Fig. 65 - the same cell as in Fig. 64, phosphomonoesterase activity (yellowgreen fluorescence) seen as small dots. Figs 66-67. Chlamydomonas sp. 2; Fig. 66 - general view of cell; Fig. 67 - cell with well visible nucleus (blue fluorescence) and intensive phosphomonoesterase activity (yellow-green fluorescence) in apical part of the cell. Figs 68-69. Carteria conf. geminata; Fig. 68 - general view of cell; Fig. 69 - whole monad together with flagella has intensive phosphomonoesterase activity (yellow fluorescence). Figs 70-71. Carteria conf. geminata and Pinnularia subcapitata; Fig. 70 - general view of the cells; Fig. 71 - phosphomonoesterase activity, more intensive enzyme activity occurs in Carteria than Pinnularia. Figs 72-73. Pinnularia permicrostauron; Fig. 72 - general view of the cells; Fig. 73 - phosphomonoesterase activity, some ELF alcohol precipitates there are seen inside the cells (yellow-green fluorescence), also nuclei are visible $(\mathbf{b l u e}$ fluorescence). Scale bar $=10 \mu \mathrm{m}$

without flagella, and stigma we cannot identify them. Many specimens were observed on the external trap wall surface.

Chlorococcal form div.

Fig. 8

Cell $15.3 \mu \mathrm{m}$ in diameter, with cape shaped chloroplast. Note: We did not observe the detailed cell morphology.

\section{Zygnematophyceae}

\section{Actinotaenium cruciferum (De Bary) Teiling}

Figs 23, 24, 58, 59

(=Cosmarium cruciferum De Bary, Disphinctium cruciferum (De Bary) Hansgirg; after Croasdale \& Flint 1988).

Cells ca. $25 \mu \mathrm{m}$ long $12.2 \mu \mathrm{m}$ wide, guitar shaped with shallow sinus, apex rounded, wall gently punctuate, chloroplast stellate. Several specimens were observed inside the traps, Common, widespread, acidophilic (Croasdale and Flint 1988).

Penium cylindrus (Ehrenberg) Brebison in Ralfs Figs 60 and 61

(=Closterium cylindrus Ehrenberg, Disphinctium cylindrus (Ehr.) Nägeli, after Croasdale \& Flint 1986).

Cells cylindrical, slightly constricted, with rounded apices, wall with coarse granules regularly dispersed, 30.5$35.0 \mu \mathrm{m}$ long, 12.2-15.0 um wide. Several specimens were observed inside the traps. Common, widespread, acidophilic (Croasdale and Flint 1986).

\section{Enzyme activity}

We detected surface phosphomonoesterases production in two dominant groups of algae (Bacillariophyceae and in Chladymonadaceae), in trap environment. Moreover, algae which live in external trap environment, in wet peat, also have surface bound activity of phosphomonoesterases. There are characteristic patterns of phosphomonoesterase activity (ELF alcohol precipitates) of the cell surface (a surface phosphomonoesterase enzymes) and in the cells of the mentioned groups of algae (intracellular enzyme activity). In Chladymonaceae ELF alcohol precipitates form dots (Figs 65 and 67), in some monads intensive phosphomonoesterase activity occurs in apical part cell near flagella (Figs 69 and 70). But also whole monad together with flagella can show intensive phosphomonoesterase activity (Fig. 67). In diatoms intensive phosphomonoesterase activity occurs in furrows, and also some ELF alcohol precipitates are seen inside the cells (Fig. 72). It should be mentioned that not all algae cells in both populations inside the traps and in external environment, show phosphomonoesterase activity.

\section{DISCUSSION}

The algal flora of Genlisea traps, with the exception of the newly described stomatocyst, consists of common cyanobacteria and algae. Among the cyanobacteria we recognize only two taxa Synechocystis aquatilis and Planktothrix conf. agardhii which occurred singly. The algal communities were represented totally by 27 taxa, including representatives of Chrysophyceae such as Chromulina bicoc$c a$, which occurred singly and a few specimens of Malomonas conf. globosa in and outside the traps. There were four morphotypes of stomatocysts, one of which is new for science. The most frequent was stomatocyst 1 Cabała covered with several spines and the newly described one which is similar to stomatocyst 1 Cabała. 
We recognized 10 diatom taxa, with Frustulia bilnearis, Pinnularia subcapitata and Eunotia exigua, the most frequent. Green algae were represented by Chlamydomonas spp. and two taxa of Carteria inside the trap. We recognized only three different vegetative forms of Chlamydomonas, which could not be identified to known taxa. The Zygnematophyceae were represented by few specimens of Actinotaenium and Penium. Among Euglenophyceae there were only Euglena mutabilis and Trachelomonas hispida. The most interesting species found in the traps was Sphaerellopsis alpina Pascher, which was described from small water bodies by Ettl 1983, but rarely reported otherwise. The majority of the reported taxa are very common and widespread. Some are classified as acidophilic: Euglena mutabilis, Pinnularia acidophila, Eunotia exigua, Actinotaenium cruciferum, and Penium cylindrus. The occurrence of these taxa is strictly connected with the peat which was brought from marshes to cultivate Genlisea. From the spectrum and ecological requirements of algal species found in the traps, environment inside the traps seems to be acidic.

As mentioned earlier, previous information about algae in Genlisea is scarce. Goebel (1891), showed on Table XV, Fig. 5, part of a desmid cell in the trap of G. aurea (G. ornata), which we identified as Euastrum sp. Later Studnička (1996, p. 15), wrote that he observed "single-cell algae (Bacillariophyceae and Desmidiales)" in the trap of Genlisea pygmaea. Płachno et al. (2005a, b) in general reported diatoms and flagellates inside the Genlisea traps and diatoms and other algae in mucilage on the leaves of G. aurea.

There are two ways of algae getting into Genlisea traps. The majority of those recorded inside the traps, are mobile; swimming freely by flagella or moving by exuding mucilage like diatoms and can colonize the traps themselves. Another possibility is transport of algae by invertebrates such as mites and crustaceans. In the case of Utricularia algae are mainly suctioned to the bladders, though, as in Genlisea some algae may be transported by animals. In any case algae in the traps of both Genlisea and Utricularia come from the surrounding environment. Gebühr et al. (2006) suggested that in Sarracenia purpurea, algae in colonize pitchers originated from air, rain and trapped insects, but not from surrounding wetland. What is the role of algae in the Genlisea traps? Are they prey? It is suggested that algae in this special environment occur in good conditions. What is more, it was observed that they can reproduce. Similarly and Hegner (1926) observed that the flagellates, Euglena sp., Heteronema acus and Phacus longicauda not only survive in Utricularia traps, but also may reproduce there. Moreover, we think that plant - host may also used nutrients, which are left by trap inhabitants and which are freed during cell lysis caused by either cell age or other reasons. Also Gebühr et al. (2006) think that in European allochthonous populations of carnivorous Sarracenia purpurea, algal biomass may be use as another source of nitrogen and phosphorus for the plants. On the other hand, it cannot be ruled out that algae in carnivorous plant traps compete with plant-host for nutrients from prey digestion (Adamec and Komárek 1999a; Jobson at al. 2000; Sirová et al. 2003). Two dominant groups of algae, in the Genlisea trap environment, show ability to hydrolyze phosphomonoseters. The Genlisea hairs have surface bound activity of phosphomonoesterase and ability to hydrolyze phosphomonoseters (Płachno et al. 2006), that we suggest, that algae in carnivorous plant traps can compete with plant-host for organic phosphate (phosphomonoseters). However, for proof this competition the biomass of algae in the trap calculation is needed. Probably all phototrophs can utilize inorganic phosphate, but some of them can also mobilize organic phosphate through surface phosphatase activity, this occurs in most cyanobacteria, algae and mosses (for detail review, see Whitton at al. 2005). In contrast to all the mentioned results, Mette et al. (2000) report, that in some aquatic Utricularia species, autotrophic organisms are also part of food spectrum; are digested as a prey. For these reasons, further studies are needed to test the relations between algae and carnivorous plants both in laboratory conditions and in natural environment.

\section{ACKNOWLEDGEMENTS}

Sincere thanks are due to Prof. Brian Whitton (University of Durham, UK) for his important discussion, criticism and linguistic correction. We also thanks to Dr Jolanta Piątek for help of the new stomatocyst description and to Dr Agata Wojtal for checking diatoms determination.

All the plates in this paper were printed thanks to PRECOPTIC Co. Warsaw.

\section{LITERATURE CITED}

ADAMEC L., KOMÁREK J. 1999a. Euglens in Utricularia traps: prey or parasites? Trifid, Prague 4: 3-5. (in Czech)

ADAMEC L., KOMÁREK. J. 1999b. Algae in traps of the bladderwort Utricularia purpurea. Trifid, Prague 4: 20-23. (in Czech)

BARTHLOTT W., POREMBSKI S., FISCHER E., GEMMEL B. 1998. First protozoa-trapping plant found. Nature 392: 447.

BOTTA S.M. 1976. Sobre las trampas las víctimas o presas de algunas especies argentinas del género Utricularia. Darwiniana 20: 127-154.

BROWN K.M., DOUGLAS M.S.V., SMOL J.P. 1994. Siliceous microfossils in a Holocene, High Arctic peat deposit (Nordvestø, Northwestern Greenland). Can. J. Bot. 72: 208-216.

BUCZKÓ K., WOJTAL A. 2005. Moss inhabiting siliceous algae from Hungarian peat bogs. Stud. Bot. Hun. 36: 21-42.

CABAŁA J. 2005. Chrysophyte stomatocysts from Staw Toporowy Wyżni peat bog in the Tatra National Park, Poland. Algol. Stud. 116: 129-146.

CAO X., ŠTROJSOVÁ J., ZNACHOR P., ZAPOMÉLOVÁ E., VRBA J., ZHOU Y. 2005. Detection of extracellular phosphatases in natural spring phytoplankton of a shallow eutrophic lake (Donghau, China). Eur. J. Phycol. 40: 251-258.

CROASDALE H., FLINT E.A. 1986. Flora of New Zealand. Freshwater algae, Chlorophyta, Desmids with ecological comments on their habitats. V. I., Botany Division, D.S.I.R. Christchurch, New Zealand $132 \mathrm{pp}$.

CROASDALE H., FLINT E.A. 1988. Flora of New Zealand. Freshwater algae, Chlorophyta, Desmids with ecological comments on their habitats. V. II Actinotaenium, Cosmarium, Cosmocladium, Spinocosmarium, Xanthidium. Botany Division, D.S.I.R. Christchurch, New Zealand 147 pp.

DUFF K.E., ZEEB B.A., SMOL J.P. 1995. Atlas of chrysophycean cysts. Kluwer Academic Publishers, Dordecht, Dev. Hydrobiol. 99: 1-189.

ELLISON A.M., GOTELLI N.J., BREWER J.S., COCHRANSTAFIRA D.L., KNEITEL J.M., MILLER T.E., WORLEY A.C., ZAMORA R. 2003. The Evolutionary Ecology of Carnivorous Plants. Adv. Ecol. Res. 33: 1-74. 
ETTL H. 1984. Die Morphologie eniger Pteromonas-Arten. Nova Hedvigia 8: 323-331.

ETTL H. 1983. Chlorophyta I Phytomonadina. In: Süsswasserflo$r a$ von Mitteleuropa, H. Ettl, G. Gärtner, H. Heynig, D. Mollenhauer (eds), 9. Spektrum, Academische Verlag, Gustav Fischer $807 \mathrm{pp}$.

FISHER E., POREMBSKI S., BARHLOTT W. 2000. Revision of the genus Genlisea (Lentibulariaceae) in Africa and Madagascar with notes on ecology and phytogeography. Nord. J.Bot. 20: 291-318.

GEBÜHR C., POHLON E., SCHMIDT A.R., KÜSEL K. 2006. Development of microalgae Communites in the phytotelmata of allochthonous populations of Sarracenia purpurea (Sarraceniaceae). Plant Biol. 8: 849-860. DOI: 10.1055/s-2006924474.

GOEBEL K. 1891. Genlisea. Lentibulariaceae. Pflanzenbiologische Schilderungen 2: 121-127, Tab. 15-16.

GRAY S.M., MILLER T.E., MOUQUET N., DAUFRESNE T. 2006. Nutrient limitations in detritus-based microcosms in Sarracenia purpurea. Hydrobiologia 573: 173-181.

HANSEN P. 2001. Chrysophyte stomatocyst in the Azores - biogeographical implications and 110 new morphotypes. Opera Bot. 138: 1-96.

HEGNER R.W. 1926. The interrelationships of protozoa and the utricles of Utricularia. Biol. Bull. 50: 239-270.

HESLOP-HARRISON Y. 1975. Enzyme release in carnivorous plants. In: Lysozymes in Biology and Pathology, J.T. Dingle, R.T. Dean (eds), North Holland Publishing Company, Amsterdam, 4, 525-578.

HUANG Z., TERPETSCHNIG E., YOU W., HAUGLAND R.P. 1992. 2-(2'-phosphoryloxyphenyl)-4 (3H)-quinazolinone derivates as fluorogenic precipitating substrates of phosphatases. Anal. Biochem. 207: 32-39.

JOBSON R.W., MORRIS E.C., BURGIN S. 2000. Carnivory and nitrogen supply affect the growth of the bladderwort Utricularia uliginosa. Aust. J. Bot. 48: 549-560.

JUNIPER B.E., ROBINS R.J., JOEL D.M. 1989. The Carnivorous Plants. Academic Press, London.

KOMÁREK J., ANAGNOSTIDIS K. 1998. Cyanoprokaryota. Teil: Chroococcales. In: Süsswasserflora von Mitteleuropa, H. Ettl, G. Gärtner, H. Heynig, D. Mollenhauer (eds), 19/1. Spektrum, Academische Verlag, Gustav Fischer, 548 pp.

KRAMER K. 2000. The genus Pinnularia. In: Diatoms of Europe. Diatoms of the European inland waters and comparable habitats, H. Lange-Beratlot (ed.), ARG. 703 pp. Gentner Verlag K.G.

KRAMER K., LANGE-BERTALOT H. 1986. Bacillariophyceae. 2/1 Teil: Bacillariaceae, Naviculaceae. Gustav Fisher Verlag, Jena, 876 pp.

KRAMER K., LANGE-BERTALOT H. 1988. Bacillariophyceae. 2 Teil: Bacillariaceae, Epithemiaceae, Surirellaceae. Gustav Fisher Verlag, Stuttgart, New York, 596 pp.

LARISON K.D., BREMILLER R., WELLS K.S., CLEMENTS I., HAUGLAND R.P. 1995. Use of a new fluorogenic phosphatase substrate in immunohistochemical applications. J. Histochem. Cytochem. 43: 77-83.

LLOYD F.E. 1942. The Carnivorous Plants. Chronica Botanica Company, Waltham, Mass., U.S.A., 352 p.

METTE N., WILBERT N., BARTHLOTT W. 2000. Food Composition of Aquatic Bladderworts (Utricularia, Lentibulariaceae) in Various Habitats. Beitr. Biol. Pflanzen 72: 1-13.

MILLER T.E., HORTH L., REEVES R. 2002. Trophic interactions in the phytotelmata communites of the pitcher plant, Sarracenia purpurea. Comm. Ecol. 3: 109-116.
MOSTO P. 1979. Algas en trampas de Utricularia oligosperma St. Hill. Bol. Socied. Argent. Bot. 18: 89-99.

NEDOMA J., ŠTROJSOVÁ A., VRBA J., KOMÁRKOVÁ J., ŠIMEK K. 2003. Extracellular phosphatase activity of natural plankton studied with ELF97 phosphate: fluorescence quantification and labelling kinetics. Environ. Microbiol. 5: 462-472.

PIĄTEK J. 2007. Chrysophyte stomatocysts from sediments in a man-made water reservoir in central Poland. Ann. Bot. Fennici 44: 186-193.

PLA S. 2001. Chrysophycean cysts from the Pyrenees. Biblioth. Phycolol. 109: 1-179.

PŁACHNO B.J., ADAMEC L., LICHTSCHEIDL I.K., PEROUTKA M., ADLASSNIG W., VRBA J. 2006. Fluorescence labelling of phosphatase activity in digestive glands of carnivorous plants. Plant Biol. 8: 813-820. DOI: 10.1055/s-2006924177.

PŁACHNO B.J, FABER J., JANKUN A. 2005a. Cuticular discontinuities in glandular hairs of Genlisea St.-Hil. in relation to their functions. Acta Bot. Gall. 152: 125-130.

PŁACHNO B.J, ADAMUS K., FABER J., KOZŁOWSKI J. 2005b. Feeding behaviour of carnivorous Genlisea plants in the laboratory. Acta Bot. Gall. 152: 159-164.

REUT M.S. 1993. Trap structure of the carnivorous plant Genlisea (Lentibulariaceae). Bot. Helvet. 103: 101-111.

RICHARDS J.H. 2001. Bladder function in Utricularia purpurea (Lentibulariaceae): is carnivory important? Am. J. Bot. 88: 170-176.

SCHUMACHER G.J. 1960. Further notes on the occurrence of desmids in Utricularia bladders. Castanea 25: 62-65.

STARMACH K. 1966. Cyanophyta-Sinice, Glasucophyta-Glaukofity. In: Flora Słodkowodna Polski, K. Starmach (ed.), T. 2 , PWN, Warszawa. 802 pp.

SIROVÁ D., ADAMEC L., VRBA J. 2003. Enzymatic activities in traps of four aquatic species of the carnivorous genus Utricularia. New Phytol. 159: 669-675.

STUDNIČKA M. 1996. Several ecophsiological observations in Genlisea. Carnivor. Plant News. 25: 14-16.

ŠTROJSOVÁ A., VRBA, J., NEDOMA J., KOMÁRKOVÁ J., ZNACHOR P. 2003. Seasonal study of extracellular phosphate expression in the phytoplankton of a eutrophic reservoir. Eur. J. Phycol. 38: 295-306.

ŠTROJSOVÁ M., VRBA J. 2005. Direct detection of digestive enzymes in planktonic rotifers using enzyme labeled fluorescence (ELF). Mar. Freshw. Res. 56: 189-195.

TAYLOR P. 1991. The genus Genlisea. Carnivor. Plant News. 20: $20-35$.

WHITTON B.A., AL-SHEHRI A.H., ELLWOOD N.T.W., TURNER B.L. 2005. Ecological aspects of phosphatase activity in cyanobacteria, eukaryotic algae and bryophytes. In: Organic Phosphorus in the Environment, B.L. Turner, E. Frossard, D.S. Baldwin (eds), Commonwealth Agricultural Bureau, Wallingford, UK pp. 205-241.

WILKINSON A.N., ZEEB B.A., SMOL J.P. 2001. Atlas of chrysophycean cysts. Volume II. Kluwer Academic Publishers, Dordecht, Dev. Hydrobiol. 157: 1-169.

WOŁOWSKI K. 1998. Taxonomic and environmental studies on Euglenophytes of the Kraków-Częstochowa Upland (Southern Poland). Fragm. Flor. Geobot. Suppl. 6: 1-192.

WOŁOWSKI K., HINDÁK F. 2005. Atlas Euglenophyttes. VEDA, Bratislava, Slovakia. $115 \mathrm{pp}$. 